\title{
Radiotherapy-Resistant Breast Cancer Cells Enhance Tumor Progression by Enhancing Premetastatic Niche Formation through the HIF-1 $\alpha$-LOX Axis
}

\author{
Young Shin Ko ${ }^{1,+}$, Trojan Rugira ${ }^{1,2,+}\left(\mathbb{D}\right.$, Hana Jin ${ }^{1}$, Young Nak Joo ${ }^{1}$ and Hye Jung Kim ${ }^{1,2, *(1)}$ \\ 1 Department of Pharmacology, Institute of Health Sciences, College of Medicine, \\ Gyeongsang National University, Jinju 52727, Korea; shini33@naver.com (Y.S.K.); \\ rugirawacu@gmail.com (T.R.); hanajin.kr@daum.net (H.J.); hahaha-_-0001@hanmail.net (Y.N.J.) \\ 2 Department of Convergence Medical Science, Gyeongsang National University, Jinju 52727, Korea \\ * Correspondence: hyejungkim@gnu.ac.kr; Tel.: +82-55-772-8074 \\ + These authors contributed equally.
}

Received: 13 October 2020; Accepted: 27 October 2020; Published: 28 October 2020

\begin{abstract}
Cancer stem cells (CSCs) exist in solid tumors and contribute to therapeutic resistance and disease recurrence. Previously, we reported that radiotherapy-resistant (RT-R)-MDA-MB-231 cells from highly metastatic MDA-MB-231 cells produced more CSCs than any other RT-R-breast cancer cells and showed therapeutic resistance and enhanced invasiveness. Hypoxia inducible factor- $1 \alpha$ (HIF-1 $\alpha)$ induced in the tumor microenvironment leads to the release of lysyl oxidase (LOX), which mediates collagen crosslinking at distant sites to facilitate environmental changes that allow cancer cells to easily metastasize. Therefore, in this study, we investigated whether RT-R-MDA-MB-231 cells induce greater HIF-1 $\alpha$ expression, LOX secretion, and premetastatic niche formation than MDA-MB-231 cells do. RT-R-MDA-MB-231 cells increased HIF-1 $\alpha$ expression and LOX secretion compared with MDA-MB-231 cells. Mice harboring RT-R-MDA-MB-231 cell xenografts showed enhanced tumor growth and higher expression of the CSC markers, CD44, Notch-4, and Oct3/4. In addition, mice injected with RT-R-MDA-MB-231 cells exhibited a higher level of HIF-1 $\alpha$ in tumor tissue, increased secretion of LOX in plasma, higher induced levels of crosslinked collagen, and a higher population of $\mathrm{CD} 11 \mathrm{~b}^{+} \mathrm{BMDC}$ recruitment around lung tissue, compared with those injected with MDA-MB-231 cells. These results suggest that RT-R-MDA-MB-231 cells contribute to tumor progression by enhancing premetastatic niche formation through the HIF-1 $\alpha$-LOX axis.
\end{abstract}

Keywords: cancer stem cell; chemotherapy resistance; radio-resistant breast cancer cell; premetastatic niche formation

\section{Introduction}

It is known that most deaths in cancer patients, including breast cancer, are due to invasion, metastasis of the primary tumor to distant organs, and recurrence of the tumor [1,2]. Generally, breast cancer patients are treated with radiotherapy, surgery, chemotherapy, hormone therapy, or target therapy [3]. Even though radiotherapy is an important treatment for breast cancer patients, some develop tumor recurrence after radiotherapy. Recently, cancer stem cells (CSCs) have been found to exist in tumors and lead to metastasis to distant organs, therapy resistance, and disease recurrence. Some or all CSCs are drivers of tumor progression and are supported by specific microenvironmental niches. The tumor microenvironment contributes to the maintenance and regeneration of CSCs [4,5] and renders CSCs more resistant to radiotherapy and chemotherapy, ultimately resulting in tumor regrowth and distant metastasis [6-10] by mediating interactions between tumor cells, their secreted factors, and the endothelium [11,12]. Recently, it has been proposed that the number of CSCs in tumor 
populations is not fixed, but the transition between CSCs and non CSCs occurs in response to the tumor environment and treatment, indicating the importance of CSC phenotype on tumor behavior [13].

In order to verify the prognostic value and usefulness of CSCs in the monitoring of therapeutic efficacy, many attempts have been made to better characterize and identify CSCs. First, Al-Hajj et al. [14] found that $\mathrm{CD} 44^{+} / \mathrm{CD} 24^{-}$breast cancer cells represent distinct characteristics of CSCs, and then several surface markers such as aldehyde dehydrogenase (ALDH), EpCAM, and LGR5 have been reported $[15,16]$. In addition, it was suggested that pathways involved in stemness and self-renewal such as Wnt [17], PI3K/Akt/FOXO [18], TGF- $\beta$ [19], and Notch [20] are dysregulated in CSCs. Furthermore, Oct4, also known as Oct-3, which belongs to the POU (Pit-Oct-Unc) transcription factor family [21], has been suggested as a CSC marker based on the reports that high Oct4 activity can be used to identify a cancer stem-like cell from breast carcinoma [22]. Oct4 has also been shown to increase tumor growth, invasion, and chemoresistance, and dedifferentiate differentiated head and neck squamous carcinoma cells to CSC-like cells [23].

In our previous study [24], we established radiotherapy-resistant (RT-R) breast cancer cells by repeated irradiation (2 Gy each, 25 times, total $50 \mathrm{~Gy}$; this is used clinically to treat breast cancer patients) and reported that RT-R-MDA-MB-231 cells derived from highly metastatic MDA-MB-231 cells showed the most radio- and chemo-resistance of the three tested cell lines (RT-R-MDA-MB-231, RT-R-MCF-7, RT-R-T47D). When we compared the response between MDA-MB-231 cells and RT-R-MDA-MB-231 cells to irradiation, irradiation reduced cell viability of MDA-MB- 231 cells by about $33 \%$ compared to non-irradiated MDA-MB-231; however, RT-R-breast cancer cells exhibited about $50 \%$ greater resistance than parental MDA-MB-231. From these results, we confirmed the successful establishment of RT-R-MDA-MB-231 cells by repeated irradiation. Furthermore, we found that RT-R-MDA-MB 231 cells increased protein levels of the CSC markers CD44, Notch-4, Oct3/4, and ALDH1 more than MDA-MB-231 cells [24].

The acquired radiotherapy-resistance can be due to the presence of hypoxia in the tumor environment [25]. It has been reported that CSCs depend largely on hypoxia inducible factors (HIFs) for survival, self-renewal, and tumor propagation [26]. Our previous study also reported that the expression of HIF-1 $\alpha$, leading to the secretion of lysyl oxidase (LOX), is increased in the highly metastatic breast cancer cells MDA-MB-231 [27]. In addition, clinical studies have shown that both HIF- $1 \alpha$ and LOX are overexpressed in breast cancer patients, and this overexpression increases with disease progression and is associated with a high mortality rate [28,29]. Accordingly, in this study, we hypothesized that in a tumor microenvironment, RT-R-MDA-MB-231 cells, which contain more CSCs than MDA-MB-231 cells, induce HIF- $1 \alpha$ expression and LOX secretion, and then finally premetastatic niche formation, more than MDA-MB-231 cells do.

\section{Results}

\subsection{RT-R-MDA-MB-231 Cells Showed Morphological Changes and Induced Colony Forming Ability and Proliferation}

We first compared the morphology between MDA-MB-231 cells and RT-R-MDA-MB-231 cells and found that the RT-R-MDA-MB-231 cells changed into a more mesenchymal form with a slightly longer shape compared with their parent MDA-MB-231 cells (Figure 1A). In addition, we examined the ability of MDA-MB-231 and RT-R-MDA-MB-231 cells to proliferate and form colonies. As expected, RT-R-MDA-MB-231 cells showed increased colony forming ability and proliferation compared with MDA-MB-231 cells (Figure 1B,C). 

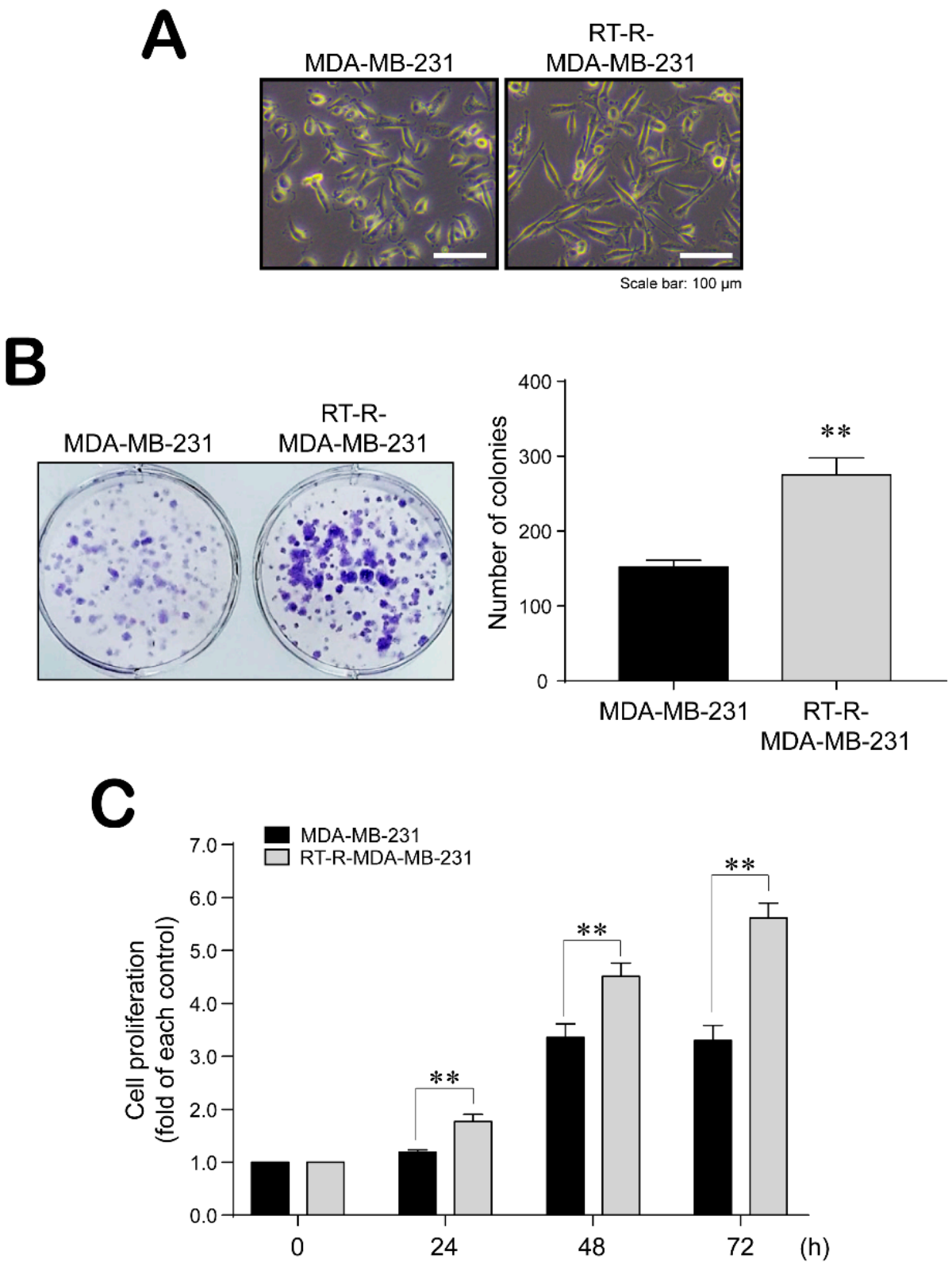

Figure 1. Radiotherapy-resistant (RT-R)-MDA-MB-231 cells showed morphological changes and enhanced colony formation and proliferation. (A) The morphologic changes of cells were observed under a light microscope $(\times 200)$. (B) The colony formation assay was performed as described in the Methods. Cells were seeded at $10^{3}$ cells in 6-well plates, and 10 days later, colonies were stained with $0.1 \%$ Giemsa staining solution. Data represent mean values \pm SEM of three independent experiments. Significance compared with MDA-MB-231, ${ }^{* *} p<0.01$. (C) Cells were seeded at $10^{4}$ cells in 24-well plates and incubated for 24,48 , and $72 \mathrm{~h}$. Cell proliferation was determined by 3-(4,5-dimethylthiazol-2-yl)-2,5-diphenyltetrazolium bromide (MTT) assay as described in the Methods. Data represent mean values \pm SEM of three independent experiments. ${ }^{* *} p<0.01$.

\subsection{RT-R-MDA-MB-231 Cells Upregulated HIF-1 $\alpha$ Expression and LOX Secretion}

It was recently reported that CSCs are induced and maintained by the tumor microenvironment, especially the hypoxic conditions that are found there [30,31]. Under hypoxic conditions, LOX is secreted to mediate premetastatic niche formation and promote cancer metastasis [27]. Thus, we analyzed HIF- $1 \alpha$ expression and LOX secretion in RT-R-MDA-MB-231 cells. As shown in Figure 2, HIF-1 $\alpha$ expression 
and LOX secretion were significantly induced in RT-R-MDA-MB-231 cells compared with MDA-MB-231 cells, supporting the existence of hypoxic conditions and suggesting the increase of radio-resistant CSCs within the RT-R-MDA-MB-231 cell population.
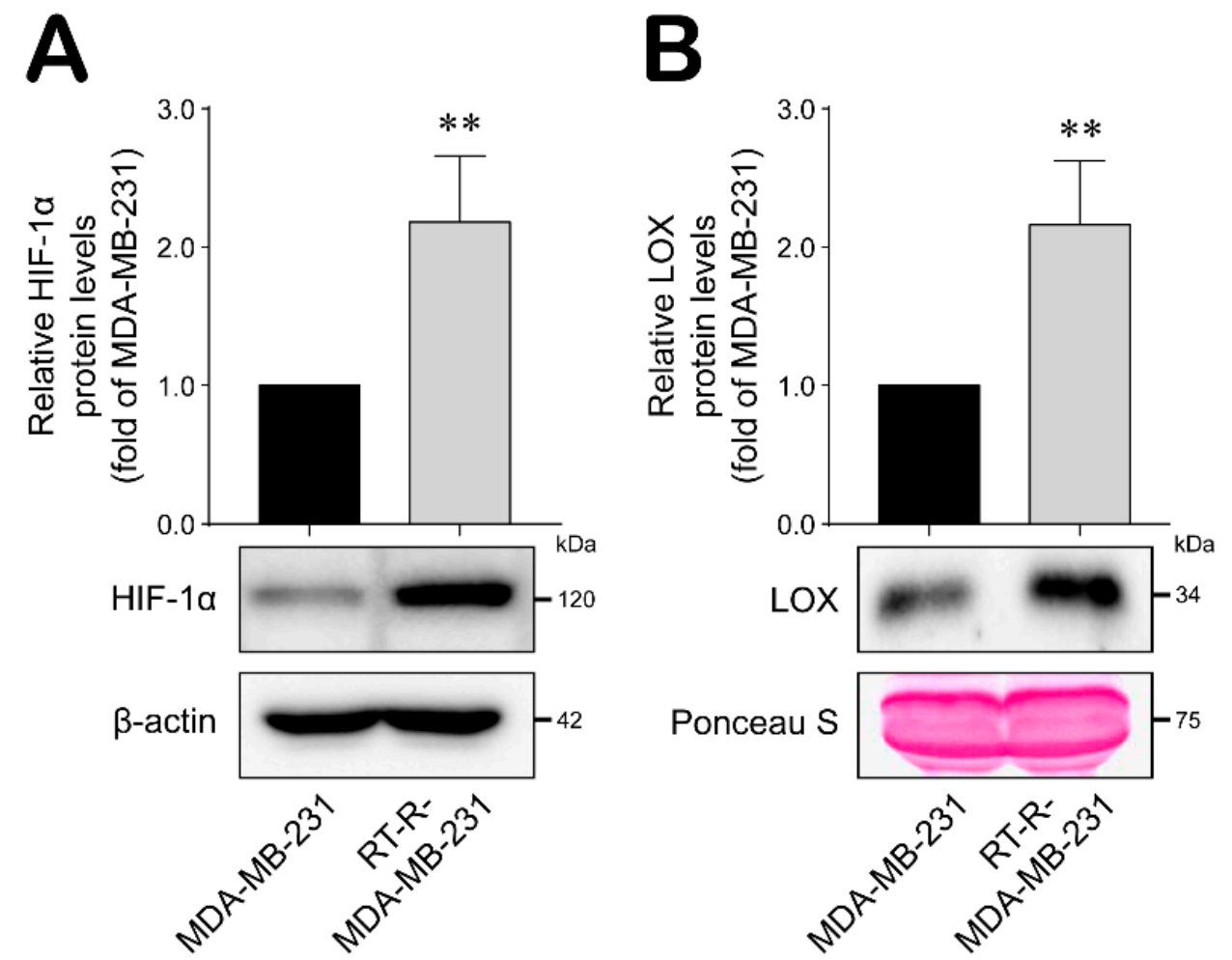

Figure 2. HIF-1 $\alpha$ expression and lysyl oxidase (LOX) secretion were increased in RT-R-MDA-MB-231 cells compared with MDA-MB-231 cells. (A,B) HIF-1 $\alpha$ expression level (A) and secreted LOX level (B) were detected from cell lysates and medium, respectively, by western blot analysis as described in the Methods. Data represent mean values \pm standard error (SEM) of three independent experiments. Significance compared with MDA-MB-231, ${ }^{* *} p<0.01$.

2.3. Mice with RT-R-MDA-MB-231 Xenografts Exhibited Increased Tumor Progression and Higher Level of CSC Markers CD44, Notch-4, and Oct3/4, But Not ALDH1

Finally, we confirmed whether RT-R-MDA-MB-231 cells increase tumor growth or invasiveness using an in vivo animal model. Female non obese diabetic-severe combined immunodeficiency (NOD-SCID) mice were divided into two groups and either MDA-MB-231 or RT-R-MDA-MB-231 cells were injected subcutaneously into the mammary fat pad. The body weights and tumor volumes were measured every 3 days for 90 days. There was no significant change in body weight (Figure 3A). Interestingly, tumors were detectable by the 16th day after injection for both MDA-MB-231 and RT-R-MDA-MB-231 xenografts; however, the RT-R-MDA-MB-231 xenografts seemed to disappear and then rapidly regrow, whereas the MDA-MB-231 tumors showed steady growth (Figure 3B). Figure $3 \mathrm{C}$ showed that the tumor volume at the end of 90 days was significantly increased in the RT-R-MDA-MB-231 group. In addition, immunohistochemistry (IHC) staining revealed that RT-R-MDA-MB-231 xenograft tissue showed a significantly higher expression of CSC markers, such as CD44, Notch-4, and Oct3/4 (Figure 4). In the case of ALDH1, its expression level looked a little higher in the mice injected with RT-R-MDA-MB-231 cells compared to those injected with MDA-MB-231, but this was not significant. 

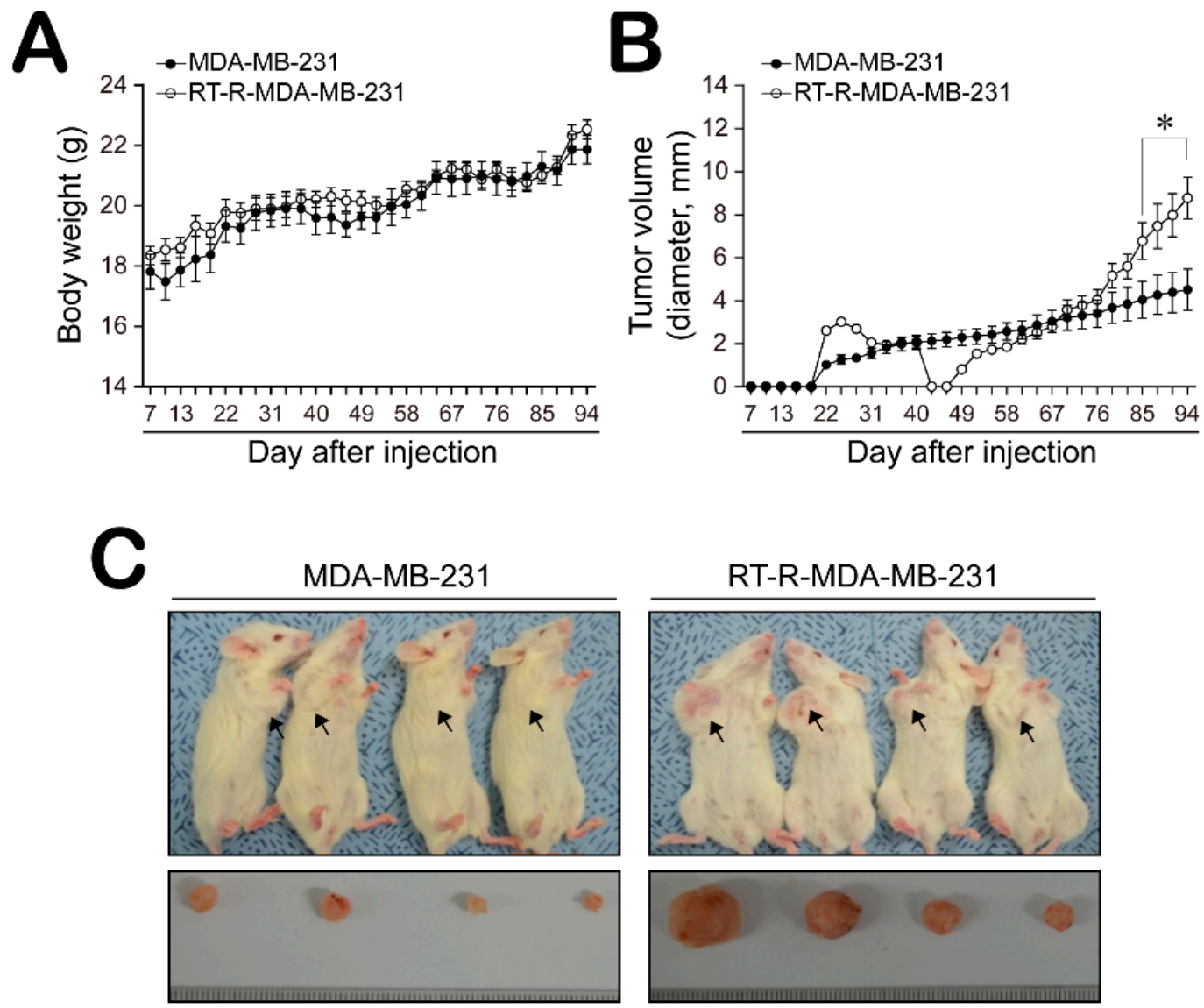

Figure 3. RT-R-MDA-MB-231 cells promoted tumor growth in an in vivo mouse model. Female non obese diabetic-severe combined immunodeficiency (NOD-SCID)mice were divided into two groups and injected subcutaneously into the mammary fat pad with MDA-MB-231 cells and RT-R-MDA-MB-231 cells $\left(5 \times 10^{6}\right.$ cells $/ 100 \mu \mathrm{L}$ of serum-free medium), respectively. Body weights $(\mathrm{A})$ and tumor volumes (B) were measured every 3 days during tumor development. MDA-MB-231-injected or RT-R-MDA-MB-231-injected animals were sacrificed at day 90 after injection, and the tumors were extracted $(\mathbf{C})\left(^{*} p<0.05\right.$, compared between MDA-MB-231- and RT-R-MDA-MB-231-injected groups). 

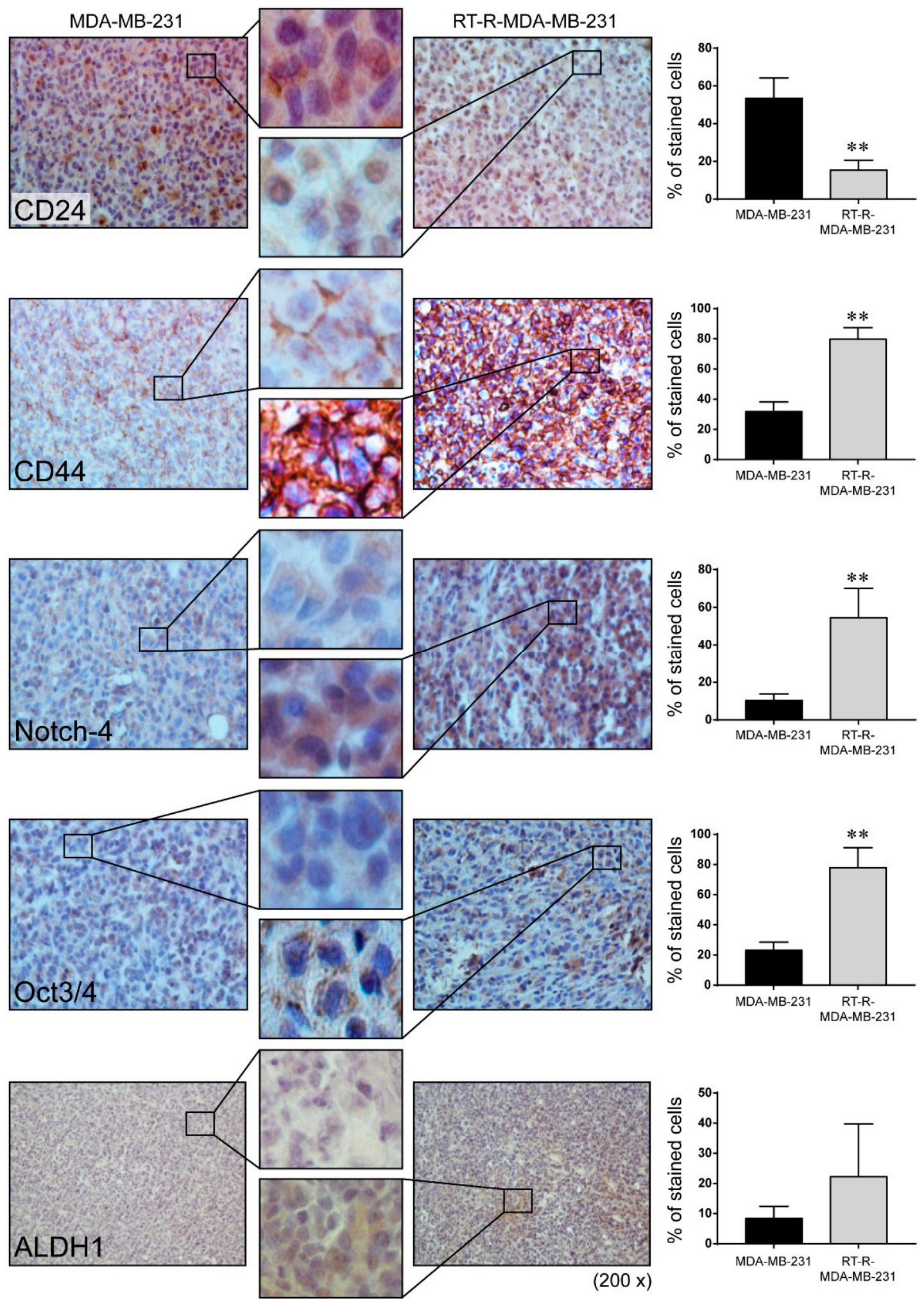

Figure 4. Cancer stem cell markers CD44, Notch-4, and Oct3/4 but not ALDH1 were highly detected in the tumor tissues from RT-R-MDA-MB-231 cell-injected mice. Cancer stem cell markers including CD24, CD44, Notch-4, Oct3/4, and ALDH1 were detected in the tumor sections using the specific antibodies as described in the Methods. The sections were counterstained with hematoxylin and examined under a light microscope. The representative images were presented (magnification; $\times 200$ and $\times 400$ ). Data represent mean values $\pm \operatorname{SEM}(n=10) .{ }^{* *} p<0.01$ compared with the MDA-MB-231-injected mice. 
2.4. Mice Injected with RT-R-MDA-MB-231 Cells Showed Increased HIF-1 $\alpha$ Expression Level, LOX Secretion, and Collagen Crosslinking and BMDC Recruitment to the Lungs Compared with Those Injected with MDA-MB-231 Cells

Mice bearing RT-R-MDA-MB-231 xenografts expressed a significantly higher level of HIF- $1 \alpha$ in tumor tissue and significantly increased plasma LOX levels compared to those with MDA-MB-231 cells (Figure 5A-C). Moreover, higher levels of crosslinked collagen were detected in lung sections from RT-R-MDA-MB-231-injected mice compared with those injected with MDA-MB-231 cells (Figure 5D). Additionally, RT-R-MDA-MB-231-injected mice showed greater recruitment of CD11b ${ }^{+}$ bone marrow-derived dendritic cells (BMDCs) around the sites of crosslinked collagen in the lungs compared with MDA-MB-231-injected mice (Figure 5D), suggesting that RT-R-MDA-MB-231 cells stimulate premetastatic niche formation.
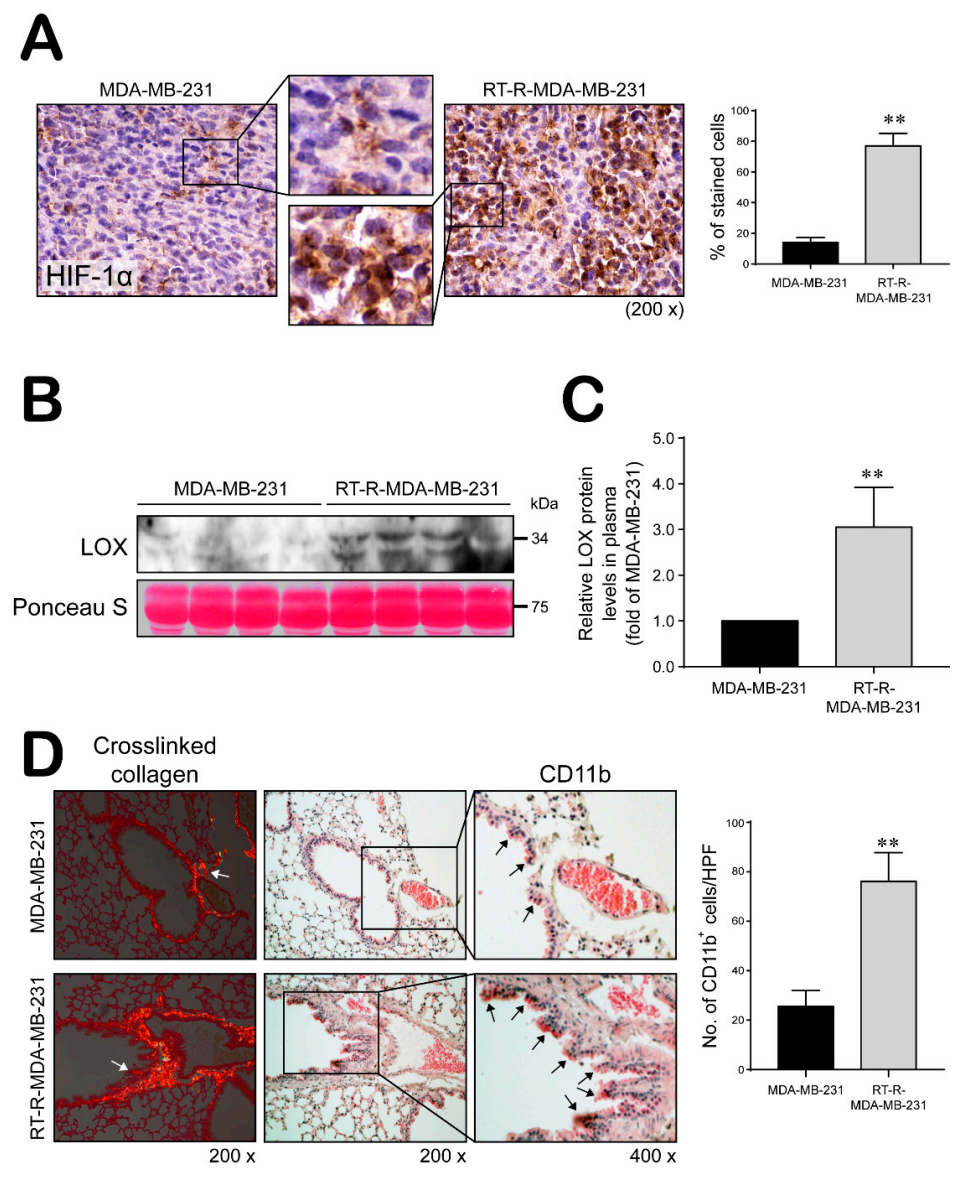

Figure 5. RT-R-MDA-MB-231 cell-injected mice increased HIF-1 $\alpha$ levels and LOX secretion, and premetastatic niche formation. (A) HIF- $1 \alpha$ levels detected in tumor section by immunohistochemistry (magnification; $\times 200$ and $\times 400)$. Data represent mean values $\pm \operatorname{SEM}(n=10) .{ }^{* *} p<0.01$ compared with the MDA-MB-231-injected mice. (B,C) Secreted LOX levels were detected in the plasma by western blot analysis. Data represent mean values $\pm \operatorname{SEM}(n=8) .{ }^{* *} p<0.01$ compared with the MDA-MB-231-injected mice. (D) Lung tissue sections from MDA-MB-231- and RT-R-MDA-MB-231-injected mice were stained with Picrosirius Red to analyze crosslinked collagen. Recruited CD11 ${ }^{+}$-immunoreactive bone marrow-derived dendritic cells (BMDCs) near the sites of collagen cross-linkage were stained with anti-CD11b antibody. White arrows indicate representative crosslinked collagen fibers. Black arrows indicate recruited CD11b ${ }^{+}$ BMDCs (magnification; $\times 200$ and $\times 400)$. Data represent mean values $\pm \operatorname{SEM}(n=10) .{ }^{* *} p<0.01$ compared with the MDA-MB-231-injected mice. 


\section{Discussion}

Combination therapy, which consists of surgery, chemotherapy, and radiotherapy, is used to treat cancer patients, including breast cancer patients. In addition to surgery and systemic therapy, radiotherapy is regarded as a crucial treatment option in modern cancer therapy as it leads to improvement in overall survival [32-34]. However, radiotherapy has limitations that can lead to therapeutic failure. Tumor recurrence after radiotherapy is common, and once the disease recurs, it readily metastasizes to distant organs and causes death. In order to metastasize to distant locations, the receptive microenvironments must be prepared for the development of cancer cells. A premetastatic niche is a fertile microenvironment that forms in a metastatic target organ and facilitates the promotion of metastasis [35]. Prior recruitment of monocytes to crosslink collagen at distant sites facilitates environmental changes that promote cancer cell colonization and metastasis [36-38].

Recent studies suggested that CSCs exist in solid tumors and contribute to therapeutic resistance and disease recurrence. In our previous study, we also reported that RT-R-breast cancer cells increased the population of CSCs. In particular, RT-R-MDA-MB-231 derived from highly metastatic breast cancer cells produced more CSCs and also acquired resistance to other cancer therapies, as well as radiotherapy. However, the role of CSCs in premetastatic niche formation is unknown. As we mentioned before, the presence of hypoxia in the tumor environment can generate CSCs and cause acquisition of radiotherapy-resistance [25], and under hypoxic conditions, HIF- $1 \alpha$ and LOX are stabilized and secreted, respectively, and mediate premetastatic niche formation to promote cancer metastasis [39]. Therefore, in this study, we chose RT-R-MDA-MB-231 cells derived from MDA-MB-231 cells, from triple negative breast cancers (TNBCs), and evaluated whether RT-R-MDA-MB-231 cells increased the levels of HIF- $1 \alpha$ and LOX. TNBC is a subtype of breast cancer characterized by a deficiency of expression of progesterone, estrogen, and epidermal growth factor receptor, and the most aggressive cancer among other breast cancer subtypes due to the lack of therapeutic target.

According to several reports, hypoxia is attributed to the HIF-dependent expression of numerous genes, including Oct-4, Notch, and ALDH1, which play roles in regulating CSC populations and stemness [40-44], and promoting tumor relapse after therapy [45]. In our previous study [24] and the present study, RT-R-MDA-MB-231 cells induced HIF-1 $\alpha$ expression both in vitro [24] and in vivo, and CSCs markers such as Oct3/4, Notch-4, and ALDH1 in vitro [24], and Oct3/4 and Notch-4 in vivo, respectively. Therefore, we suggest that RT-R-MDA-MB-231 cells increase CSCs through induction of HIF- $1 \alpha$-dependent expression of CSC markers such as Oct3/4, Notch-4, and/or ALDH1. Interestingly, in contrast to our in vitro study, which showed that RT-R-MDA-MB-231 cells significantly increased the expression of CSC markers CD44, Notch4, and OCT3/4 including ALDH1 compared to MDA-MB-231 [24]. Tumor tissue in RT-R-MDA-MB-231-injected mice showed significant increases in the expression of CD44, Notch-4, and Oct3/4, but not ALDH1 in the present study. This result corresponded with the clinical study in patients with breast cancer, where CD44, Oct3/4, and Notch-4, but not ALDH1A1, were significantly expressed in the tumor tissues compared with the normal epithelial tissues of patients with breast cancer [46]. These results suggest that the phenotype of cancer cells can change under different microenvironments in vivo, as supported by Prasetyanti and Medema [47].

Moreover, RT-R-MDA-MB-231-injected mice showed significantly increased plasma LOX levels and a higher level of $C D 11 b^{+}$BMDC recruitment around the sites of crosslinked collagen in the lungs compared with mice injected with MDA-MB-231 cells, suggesting that RT-R-MDA-MB-231 cells stimulate premetastatic niche formation in vivo through activation of the HIF- $1 \alpha$-LOX axis. LOX is known as an enzyme that crosslinks extracellular matrix proteins such as collagen and promotes breast cancer metastasis, and the release of LOX is regulated by HIF-1 $\alpha$ [38]. However, in this study, we failed to observe metastasis to the lungs in mice injected with RT-R-MDA-MB-231 or MDA-MB-231 cells, perhaps because the experimental conditions differed from those in our previous study [48]. In the present study, we used NOD-SCID (deficient for B and T cells but not NK cells) with the expectation that these more severely immunodeficient mice would show obvious metastases; however, we did not 
observe metastases even in RT-R-MDA-MB-231 cell-injected mice. The tumors in mice injected with RT-R-MDA-MB-231 cells showed recurrence and faster growth than mice injected with MDA-MB-231 cells, but these disappeared during the early phase. We assume that NK cells might be important for mitigating cancer cell activity, and CSCs have the ability to promote disease recurrence. Because the premetastatic niche was formed in the lungs of both groups of mice, albeit to a greater extent in the mice injected with RT-R-MDA-MB-231 cells, we plan to further study the effects of NK cells on CSC-mediated metastasis and recurrence.

\section{Conclusions}

Taken together, this study suggests that RT-R-MDA-MB-231 cells derived from highly metastatic TNBCs increase HIF- $1 \alpha$ expression, leading to secretion of LOX, which contributes to tumor progression by enhancing premetastatic niche formation (Figure 6).

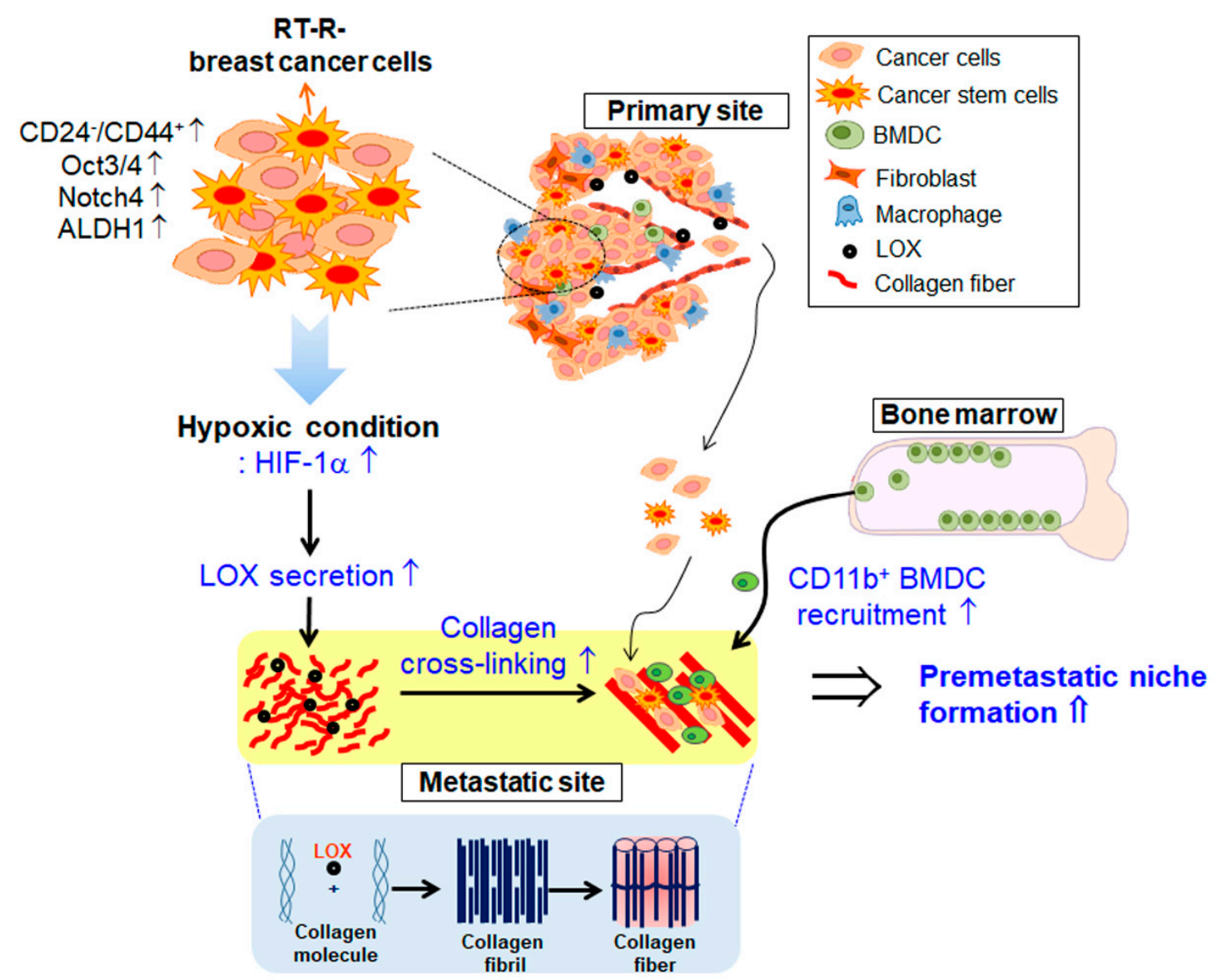

Figure 6. Schematic representation by which RT-R-breast cancer cells increase HIF-1 $\alpha$ expression, leading to secretion of LOX, which contributes to tumor progression by enhancing premetastatic niche formation.

\section{Materials and Methods}

\subsection{Materials}

RPMI 1640 medium, fetal bovine serum (FBS), and antibiotics (penicillin/streptomycin) were purchased from HyClone (South Logan, UT, USA). Anti-HIF-1 $\alpha$, anti-LOX, anti-Oct3/4, and anti-Notch-4 antibodies were purchased from Santa Cruz Biotechnology (Santa Cruz, CA, USA). Anti-CD11b and anti-ALDH1 antibodies were purchased from Abcam (Cambridge, UK). Enhanced chemiluminescence 
(ECL) western blotting detection reagent was obtained from Bio-Rad (Hercules, CA, USA). 3,3'-Diaminobenzidine tetrahydrochloride (DAB) immunostaining detection reagent was obtained from Thermo Fisher Scientific (Waltham, MA, USA). All other chemicals were purchased from Sigma-Aldrich (St. Louis, MO, USA).

\subsection{Cell Culture and Establishment of RT-R-Breast Cancer Cells}

The human breast cancer cell line MDA-MB-231 was obtained from the Korea Cell Line Bank (Seoul, Korea) and grown in RPMI 1640 supplemented with 10\% FBS, 1\% penicillin, and streptomycin. RT-R-MDA-MB-231 cells were generated by applying the cells with fractionated small doses (2 Gy) of $X$-ray irradiation until a final dose of $50 \mathrm{~Gy}$ was reached as described by Ko et al. [24]. The generation of RT-R-MDA-MB-231 cells was confirmed based on cell viability after exposure to radiation treatment [24]. RT-R-MDA-MB-231 cells were used through 5 passages.

\subsection{Cell Proliferation Assay}

Cells were seeded at $10^{4}$ cells per well in 24 -well plates. Cells were incubated at $37^{\circ} \mathrm{C}$ for 24,48 , and $72 \mathrm{~h}$. After removal of media, a new medium containing $0.1 \mathrm{mg} / \mathrm{mL}$ MTT was added onto the cells and incubated for an additional $3 \mathrm{~h}$. Then, the supernatants were aspirated, and the formazan crystals were dissolved with $200 \mu \mathrm{L}$ of $4 \mathrm{~N} \mathrm{HCl}$-isopropanol in each well. The optical density of the colored product was measured at $570 \mathrm{~nm}$, as suggested by the manufacturer, using an Infinite 200 microplate reader (TECAN, GmbH, Grödig, Austria).

\subsection{Colony Formation Assay}

Cells were seeded in 6-well plates at $10^{3}$ cells/well. Culture medium was changed with new media every 2-3 days. After 10 days, the medium was discarded, and each well was washed with phosphate buffered saline (PBS). The colonies were fixed in 100\% methanol for $10 \mathrm{~min}$ at room temperature and then stained with $0.1 \%$ Giemsa staining solution for $30 \mathrm{~min}$ at room temperature and photographed.

\subsection{Western Blot Analysis}

Cells were harvested and lysed with a radioimmunoprecipitation assay (RIPA)buffer containing $50 \mathrm{mM}$ Tris- $\mathrm{HCl}$ (pH 7.5), $150 \mathrm{mM} \mathrm{NaCl}, 1 \% \mathrm{NP}-40,0.1 \%$ SDS, $0.5 \%$ sodium deoxycholate, and protease inhibitors. The samples were centrifuged at $13000 \mathrm{rpm}$ for $20 \mathrm{~min}$ at $4{ }^{\circ} \mathrm{C}$, and the supernatants were collected for determination of the protein concentration using the Bradford method. Aliquots of $30-50 \mu \mathrm{g}$ of protein were subjected to $8-10 \%$ sodium dodecyl sulfate-polyacrylamide gel electrophoresis (SDS-PAGE) gel for $2 \mathrm{~h}$ at $100 \mathrm{~V}$. For the detection of secreted LOX in medium, proteins in conditioned media were concentrated 20-fold with Pierce concentrator $7 \mathrm{~mL} / 9 \mathrm{~K}$, MWCO devices (Thermo Fisher Scientific). The separated proteins in the SDS-polyacrylamide gel were transferred onto Hybond- $\mathrm{P}^{+}$ polyvinylidene difluoride membranes (GE Healthcare, Little Chalfont, UK). The membranes were blocked with $5 \%$ nonfat milk in Tris-buffered saline containing $0.05 \%$ Tween-20 for $1 \mathrm{~h}$ at room temperature and then incubated with the primary antibodies: anti-HIF-1 $\alpha$ (ab2185; 1:1000, Abcam) and anti-LOX (sc-32409; 1:1000, Santa Cruz Biotechnology, Dallas, TX, USA) antibodies. The bound antibodies were detected with horseradish peroxidase-conjugated secondary antibodies and an enhanced chemiluminescence (ECL) western blotting detection reagent.

\subsection{Animal Experiments}

Female NOD-SCID mice (Animal Resources Center; ARC, Australia) were divided into 2 groups (10 mice/group), and injected subcutaneously into the mammary fat pad with MDA-MB-231 cells and RT-R-MDA-MB-231 cells $\left(5 \times 10^{6}\right.$ cells/100 $\mu \mathrm{L}$ of serum-free medium), respectively. The experimental protocol was approved by the Institutional Animal Care and Use Committee at Gyeongsang National University (approval number: GLA-120208-M004). Body weights and tumor volumes were measured 
every 3 days starting 7 days after injection. At the end of 90 days, the mice were sacrificed. The plasma LOX levels in mice injected with RT-R-MDA-MB-231 or MDA-MB-231 cells were determined by western blot analysis. Lung and tumor tissues were fixed in 10\% formalin at room temperature, followed by paraffin infiltration and embedding. Sections of $5 \mu \mathrm{m}$ were mounted onto gelatin-coated slides, and immunohistochemical analysis was performed using anti-CD44 (ab51037; 1:100, Abcam), anti-CD24 (sc-11406; 1:100, Santa Cruz Biotechnology), anti-Oct3/4 (sc-9081; 1:100, Santa Cruz Biotechnology), anti-Notch-4 (sc-5594; 1:100, Santa Cruz Biotechnology), anti-ALDH1 (ab52492; 1:100, Abcam), and anti-HIF-1 $\alpha$ (ab2185; 1:100, Abcam) antibodies. After antibody staining, the sections were counterstained with hematoxylin and examined under a light microscope. Picrosirius Red (Sigma-Aldrich) was used for staining fibrillar collagen. After staining with the CD11b antibody (ab8878; 1:100, Abcam) and Picrosirius Red, sections were counterstained with hematoxylin. Representative areas of Picrosirius Red-stained lung sections were imaged under a polarized microscope (BX-51P, Olympus, Tokyo, Japan). The expression of the parameters under examination (CD24, CD44, Notch-4, Oct3/4 ALDH1, and HIF1 $\alpha$ ) was evaluated by counting the cells stained with each antibody and presenting the percentage of stained cells with each antibody in the tumor region.

\subsection{Statistical Evaluations}

Scanning densitometry was performed using Image Master ${ }^{\circledR}$ VDS (Pharmacia Biotech Inc., San Francisco, CA, USA). The treatment groups were compared using one-way analysis of variance and Tukey's multiple comparisons test. The data are presented as the mean \pm standard error (SEM).

Author Contributions: Y.S.K. performed the experiments and statistical analyses; T.R. performed the experiments and wrote the draft; H.J. performed statistical analyses and revised the manuscript; Y.N.J. performed animal experiments; H.J.K. designed the study, conceived of the hypothesis, directed the project, and wrote the manuscript. All authors have read and agreed to the published version of the manuscript.

Funding: This work was supported by the Basic Science Research Program through the National Research Foundation of Korea (NRF) funded by the Ministry of Education, Science and Technology (2018R1A2B6001786).

Conflicts of Interest: The authors declare that they have no competing interest.

$\begin{array}{ll}\text { Abbreviations } & \\ \text { ALDH1 } & \text { aldehyde dehydrogenase 1 } \\ \text { BCSC } & \text { breast cancer stem cell } \\ \text { BMDCs } & \text { bone marrow-derived dendritic cells } \\ \text { CSC } & \text { cancer stem cell } \\ \text { ECL } & \text { enhanced chemiluminescence } \\ \text { FBS } & \text { fetal bovine serum } \\ \text { HIF } & \text { hypoxia inducible factor } \\ \text { LOX } & \text { lysyl oxidase } \\ \text { MTT } & \text { 3-(4,5-dimethylthiazol-2-yl)-2,5-biphenyl tetrazolium bromide } \\ \text { PBS } & \text { phosphate-buffered saline } \\ \text { NOD-SCID } & \text { non obese diabeticsevere combined immunodeficiency } \\ \text { SDS-PAGE } & \text { sodium dodecyl sulfate-polyacrylamide gel electrophoresis } \\ \text { SEM } & \text { standard error } \\ \text { RIPA } & \text { Radioimmunoprecipitation assay } \\ \text { RT-R } & \text { radiotherapy-resistant } \\ \text { TNBC } & \text { triple negative breast cancer }\end{array}$




\section{References}

1. Guo, B.H.; Feng, Y.; Zhang, R.; Xu, L.H.; Li, M.Z.; Kung, H.F.; Song, L.B.; Zeng, M.S. Bmi-1 promotes invasion and metastasis, and its elevated expression is correlated with an advanced stage of breast cancer. Mol. Cancer 2011, 101, 10. [CrossRef]

2. Weigelt, B.; Peterse, J.L.; van't Veer, L.J. Breast cancer metastasis: Markers and models. Nat. Rev. Cancer 2005, 5, 591-602. [CrossRef]

3. Nounou, M.I.; Elamrawy, F.; Ahmed, N.; Abdelraouf, K.; Goda, S.; Syed-sha-qhattal, H. Breast Cancer: Conventional Diagnosis and Treatment Modalities and Recent Patents and Technologies. Breast Cancer 2015, 9, 17-34. [CrossRef]

4. Malanchi, I.; Santamaria-Martinez, A.; Susanto, E.; Peng, H.; Lehr, H.A.; Delaloye, J.F.; Huelsken, J. Interactions between cancer stem cells and their niche govern metastatic colonization. Nature 2012, 481, 85-89. [CrossRef]

5. Ye, J.; Wu, D.; Wu, P.; Chen, Z.; Huang, J. The cancer stem cell niche: Cross talk between cancer stem cells and their microenvironment. Tumor Biol. 2014, 35, 3945-3951. [CrossRef]

6. Bertolini, G.; Roz, L.; Perego, P.; Tortoreto, M.; Fontanella, E.; Gatti, L.; Pratesi, G.; Fabbri, A.; Andriani, F.; Tinelli, S.; et al. Highly tumorigenic lung cancer $\mathrm{CD} 133^{+}$cells display stem-like features and are spared by cisplatin treatment. Proc. Natl. Acad. Sci. USA 2009, 106, 16281-16286. [CrossRef]

7. Creighton, C.J.; Li, X.; Landis, M.; Dixon, J.M.; Neumeister, V.M.; Sjolund, A.; Rimm, D.L.; Wong, H.; Rodriguez, A.; Herschkowitz, J.I.; et al. Residual breast cancers after conventional therapy display mesenchymal as well as tumor-initiating features. Proc. Natl. Acad. Sci. USA 2009, 106, 13820-13825. [CrossRef] [PubMed]

8. Li, X.; Lewis, M.T.; Huang, J.; Gutierrez, C.; Osborne, C.K.; Wu, M.F.; Hilsenbeck, S.G.; Pavlick, A.; Zhang, X.; Chamness, G.C.; et al. Intrinsic resistance of tumorigenic breast cancer cells to chemotherapy. J. Natl. Cancer Inst. 2008, 100, 672-679. [CrossRef] [PubMed]

9. Phillips, T.M.; McBride, W.H.; Pajonk, F. The response of CD24-/low $/ C D 44^{+}$breast cancer-initiating cells to radiation. J. Natl. Cancer Inst. 2006, 98, 1777-1785. [CrossRef] [PubMed]

10. Abraham, B.K.; Fritz, P.; McClellan, M.; Hauptvogel, P.; Athelogou, M.; Brauch, H. Prevalence of $\mathrm{CD} 44^{+} / \mathrm{CD} 24^{-} / \mathrm{low}$ cells in breast cancer may not be associated with clinical outcome but may favor distant metastasis. Clin. Cancer Res. 2005, 11, 1154-1159. [PubMed]

11. Desgrosellier, J.S.; Cheresh, D.A. Integrins in cancer: Biological implications and therapeutic opportunities. Nat. Rev. Cancer 2010, 10, 9-22. [CrossRef] [PubMed]

12. Joyce, J.A.; Pollard, J.W. Microenvironmental regulation of metastasis. Nat. Rev. Cancer 2009, 9, $239-252$. [CrossRef] [PubMed]

13. Reid, P.; Marcu, L.G.; Olver, I.; Moghaddasi, L.; Staudacher, A.H.; Eva Bezak, E. Diversity of cancer stem cells in head and neck carcinomas: The role of HPV in cancer stem cell heterogeneity, plasticity and treatment response. Radiother. Oncol. 2019, 135, 1-12. [CrossRef] [PubMed]

14. Al-Hajj, M.; Wicha, M.S.; Benito-Hernandez, A.; Morrison, S.J.; Clarke, M.F. Prospective identification of tumorigenic breast cancer cells. Proc. Natl. Acad. Sci. USA 2003, 100, 3983-3988. [CrossRef]

15. Ginestier, C.; Hur, M.H.; Charafe-Jauffret, E.; Monville, F.; Dutcher, J.; Brown, M.; Jacquemier, J.; Viens, P.; Kleer, C.G.; Liu, S.; et al. ALDH1 is a marker of normal and malignant human mammary stem cells and a predictor of poor clinical outcome. Cell Stem Cell 2007, 1, 555-567. [CrossRef]

16. Yang, L.; Tang, H.; Kong, Y.; Xie, X.; Chen, J.; Song, C.; Liu, X.; Ye, F.; Li, N.; Wang, N.; et al. LGR5 Promotes Breast Cancer Progression and Maintains Stem-Like Cells Through Activation of Wnt/beta-Catenin Signaling. Stem Cells 2015, 33, 2913-2924. [CrossRef]

17. Takahashi-Yanaga, F.; Kahn, M. Targeting Wnt signaling: Can we safely eradicate cancer stem cells? Clin. Cancer Res. 2010, 16, 3153-3162. [CrossRef]

18. Smit, L.; Berns, K.; Spence, K.; Ryder, W.D.; Zeps, N.; Madiredjo, M.; Beijersbergen, R.; Bernards, R.; Clarke, R.B. An integrated genomic approach identifies that the PI3K/AKT/FOXO pathway is involved in breast cancer tumor initiation. Oncotarget 2016, 7, 2596. [CrossRef]

19. Woosley, A.N.; Dalton, A.C.; Hussey, G.S.; Howley, B.V.; Mohanty, B.K.; Grelet, S.; Dincman, T.; Bloos, S.; Olsen, S.K.; Howe, P.H. TGFbeta promotes breast cancer stem cell self-renewal through an ILEI/LIFR signaling axis. Oncogene 2019, 38, 3794-3811. [CrossRef] 
20. Zhang, L.; Ridgway, L.D.; Wetzel, M.D.; Ngo, J.; Yin, W.; Kumar, D.; Goodman, J.C.; Groves, M.D.; Marchetti, D. The identification and characterization of breast cancer CTCs competent for brain metastasis. Sci. Transl. Med. 2013, 5, 180ra48. [CrossRef]

21. Scholer, H.; Ruppert, S. New type of POU domain in germ line-specific protein Oct-4. Nature 1990, 344, 435-439. [CrossRef] [PubMed]

22. Jung, J.W.; Park, S.B.; Lee, S.J. Metformin represses self-renewal of the human breast carcinoma stem cells. PLOS ONE 2011, 6, e28068. [CrossRef] [PubMed]

23. Koo, B.S.; Lee, S.H.; Kim, J.M.; Huang, S.; Kim, S.H.; Rho, Y.S.; Bae, W.J.; Kang, H.J.; Kim, Y.S.; Moon, J.H.; et al. Oct4 is a critical regulator of stemness in head and neck squamous carcinoma cells. Oncogene 2015, 34, 2317-2324. [CrossRef]

24. Ko, Y.S.; Jin, H.; Lee, J.S.; Park, S.W.; Chang, K.C.; Kang, K.M.; Jeong, B.K.; Kim, H.J. Radio-resistant breast cancer cells derived from highly metastatic breast cancer cells exhibit increased resistance to chemotherapy and enhanced invasive properties due to cancer stem cells. Oncol. Rep. 2018, 40, 3752-3762. [CrossRef]

25. Gray, M.; Turnbull, A.K.; Ward, C.; Meehan, J.; Martínez-Pérez, C.; Bonello, M.; Pang, L.Y.; Langdon, S.P.; Kunkler, I.H.; Murray, A.; et al. Development and characterisation of acquired radioresistant breast cancer cell lines. Radiat. Oncol. 2019, 14, 64. [CrossRef] [PubMed]

26. Heddleston, J.M.; Li, Z.; Lathia, J.D.; Bao, S.; Hjelmeland, A.B.; Rich, J.N. Hypoxia inducible factors in cancer stem cells. Br. J. Cancer 2010, 102, 789-795. [CrossRef] [PubMed]

27. Joo, Y.N.; Jin, H.; Eun, S.Y.; Park, S.W.; Chang, K.C.; Kim, H.J. P2Y2R activation by nucleotides released from the highly metastatic breast cancer cell MDA-MB-231 contributes to pre-metastatic niche formation by mediating lysyl oxidase secretion, collagen crosslinking, and monocyte recruitment. Oncotarget 2014, 5, 9322-9334. [CrossRef]

28. Bos, R.; van der Groep, P.; Greijer, A.E.; Shvarts, A.; Meijer, S.; Pinedo, H.M.; Semenza, G.L.; van Diest, P.J.; van der Wall, E. Levels of hypoxia-inducible factor $1 \alpha$ independently predict prognosis in patients with lymph node negative breast carcinoma. Cancer 2003, 97, 1573-1581. [CrossRef]

29. Chang, H.Y.; Nuyten, D.S.; Sneddon, J.B.; Hastie, T.; Tibshirani, R.; Sørlie, T.; Dai, H.; He, Y.D.; van't Veer, L.J.; Bartelink, H.; et al. Robustness, scalability, and integration of a wound response gene expression signature in predicting breast cancer survival. Proc. Natl. Acad. Sci. USA 2005, 102, 3738-3743. [CrossRef]

30. Mohyeldin, A.; Garzón-Muvdi, T.; Quiñones-Hinojosa, A. Oxygen in stem cell biology: A critical component of the stem cell niche. Cell Stem Cell 2010, 7, 150-161. [CrossRef]

31. Marie-Egyptienne, D.T.; Lohse, I.; Hill, R.P. Cancer stem cells, the epithelial to mesenchymal transition (EMT) and radioresistance: Potential role of hypoxia. Cancer Lett. 2013, 341, 63-72. [CrossRef] [PubMed]

32. Clarke, M.; Collins, R.; Darby, S.; Davies, C.; Elphinstone, P.; Evans, V.; Godwin, J.; Gray, R.; Hicks, C.; James, S.; et al. Effects of radiotherapy and of differences in the extent of surgery for early breast cancer on local recurrence and 15-year survival: An overview of the randomised trials. Lancet 2005, 366, 2087-2106. [CrossRef]

33. Veronesi, U.; Boyle, P.; Goldhirsch, A.; Orecchia, R.; Viale, G. Breast cancer. Lancet 2005, 365, $1727-1741$. [CrossRef]

34. Gebski, V.; Lagleva, M.; Keech, A.; Simes, J.; Langlands, A.O. Survival effects of postmastectomy adjuvant radiation therapy using biologically equivalent doses: A clinical perspective. J. Natl. Cancer Inst. 2006, 98, 26-38. [CrossRef] [PubMed]

35. Zoccoli, A.; Iuliani, M.; Pantano, F.; Imperatori, M.; Intagliata, S.; Vincenzi, B.; Marchetti, P.; Papapietro, N.; Denaro, V.; Tonini, G.; et al. Premetastatic niche: Ready for new therapeutic interventions? Expert Opin. Ther. Targets 2012, 2, S119-S129. [CrossRef]

36. Erler, J.T.; Bennewith, K.L.; Cox, T.R.; Lang, G.; Bird, D.; Koong, A.; Le, Q.T.; Giaccia, A.J. Hypoxia-induced lysyl oxidase is a critical mediator of bone marrow cell recruitment to form the premetastatic niche. Cancer Cell 2009, 15, 35-44. [CrossRef]

37. Kaplan, R.N.; Riba, R.D.; Zacharoulis, S.; Bramley, A.H.; Vincent, L.; Costa, C.; MacDonald, D.D.; Jin, D.K.; Shido, K.; Kerns, S.A.; et al. VEGFR1-positive haematopoietic bone marrow progenitors initiate the pre-metastatic niche. Nature 2005, 438, 820-827. [CrossRef]

38. Wong, C.C.; Gilkes, D.M.; Zhang, H.; Chen, J.; Wei, H.; Chaturvedi, P.; Fraley, S.I.; Wong, C.M.; Khoo, U.S.; $\mathrm{Ng}$, I.O.; et al. Hypoxia- inducible factor 1 is a master regulator of breast cancer metastatic niche formation. Proc. Natl. Acad. Sci. USA 2011, 108, 16369-16374. [CrossRef] 
39. Erler, J.T.; Giaccia, A.J. Lysyl oxidase mediates hypoxic control of metastasis. Cancer Res. 2006, 66, 10238-10241. [CrossRef]

40. Weng, A.P.; Aster, J.C. Multiple niches for Notch in cancer: Context is everything. Curr. Opin. Genet. Dev. 2004, 14, 48-54. [CrossRef]

41. Weng, A.P.; Millholland, J.M.; Yashiro-Ohtani, Y.; Arcangeli, M.L.; Lau, A.; Wai, C.; Del Bianco, C.; Rodriguez, C.G.; Sai, H.; Tobias, J.; et al. c-Myc is an important direct target of Notch1 in T-cell acute lymphoblastic leukemia/lymphoma. Genes Dev. 2006, 20, 2096-2109. [CrossRef] [PubMed]

42. Covello, K.L.; Kehler, J.; Yu, H.; Gordan, J.D.; Arsham, A.M.; Hu, C.J.; Labosky, P.A.; Simon, M.C.; Keith, B. HIF-2alpha regulates Oct-4: Effects of hypoxia on stem cell function, embryonic development, and tumor growth. Genes Dev. 2006, 20, 557-570. [CrossRef] [PubMed]

43. Keith, B.; Simon, M.C. Hypoxia-inducible factors, stem cells, and cancer. Cell 2007, 129, 465-472. [CrossRef]

44. Liu, L.; Salnikov, A.V.; Bauer, N.; Aleksandrowicz, E.; Labsch, S.; Nwaeburu, C.; Mattern, J.; Gladkich, J.; Schemmer, P.; Werner, J.; et al. Triptolide reverses hypoxia-induced epithelial-mesenchymal transition and stem-like features in pancreatic cancer by NF-kB downregulation. Int. J. Cancer 2014, 134, 2489-2503. [CrossRef] [PubMed]

45. Diehn, M.; Clarke, M.F. Cancer stem cells and radiotherapy: New insights into tumor radioresistance. J. Natl. Cancer Inst. 2006, 98, 1755-1757. [CrossRef]

46. Kim, D.C.; Jin, H.; Lee, J.S.; Son, E.; Lee, G.W.; Kim, H.J. P2 $\mathrm{Y}_{2} \mathrm{R}$ has a significant correlation with Notch-4 of cancer stem cell markers in breast cancer patients. Oncol. Lett. 2020, 20, 647-654. [CrossRef] [PubMed]

47. Prasetyanti, P.R.; Medema, J.P. Intra-tumor heterogeneity from a cancer stem cell perspective. Mol. Cancer 2017, 16, 41. [CrossRef] [PubMed]

48. Jin, H.; Eun, S.Y.; Lee, J.S.; Park, S.W.; Lee, J.H.; Chang, K.C.; Kim, H.J. P2Y2 receptor activation by nucleotides released from highly metastatic breast cancer cells increases tumor growth and invasion via crosstalk with endothelial cells. Breast Cancer Res. 2014, 16, R77. [CrossRef]

Publisher's Note: MDPI stays neutral with regard to jurisdictional claims in published maps and institutional affiliations.

(C) 2020 by the authors. Licensee MDPI, Basel, Switzerland. This article is an open access article distributed under the terms and conditions of the Creative Commons Attribution (CC BY) license (http://creativecommons.org/licenses/by/4.0/). 